\title{
Production of potent antimicrobial agent by actinomycete, Streptomyces sannanensis strain SU118 isolated from phoomdi in Loktak Lake of Manipur, India
}

\author{
Laishram Shantikumar Singh ${ }^{1 *}$, Hemant Sharma ${ }^{1}$ and Narayan Chandra Talukdar ${ }^{2}$
}

\begin{abstract}
Background: Actinomycetes have provided a wealth of bioactive secondary metabolites with interesting activities such as antimicrobial, antiviral and anticancer. The study aims at isolation, characterization and the antimicrobial potentiality of Streptomyces sannanensis SU118 obtained from Phoomdi, a unique habitat of Loktak Lake of Manipur, India.

Results: An actinomycete strain isolated from Phoomdi soil of Loktak Lake of Manipur, India was identified as Streptomyces sannanensis SU118. It is a Gram-positive filamentous bacterium which exhibits antimicrobial activity only against Gram-positive bacteria, while Gram-negative organisms were not affected. Glucose Soyabean meal broth was found to be the suitable medium for antibiotic production at $28^{\circ} \mathrm{C}$ for seven days of incubation. The antimicrobial agent produced by the strain was extracted with ethyl acetate as solvent and purified by thin layer chromatography. Screening and bioassay - guided fractionation of the ethyl acetate extract from the culture filtrate led to the isolation of an active potential compound $\left(R_{f}\right.$ value 0.56 ) with $\lambda_{\max } 275.0 \mathrm{~nm}$ which has got the lowest minimum inhibitory concentration $(0.5 \mu \mathrm{g} / \mathrm{ml})$ against Staphylococcus aureus MTCC 96 and Staphylococcus aureus (clinical isolate), whereas highest (3.0 $\mathrm{\mu g} / \mathrm{ml})$ was recorded against Mycobacterium smegmatis MTCC 6 and Bacillus circulans MTCC 8074.

Conclusion: This study has therefore uncovered the potential of exploring virgin untapped habitats in the Indo-Burma biodiversity hot spot region as reservoir of promising antimicrobial metabolite producer. These results highlighted the scope for further characterization of the metabolite and could be a candidate in the generation of new antimicrobial agents.
\end{abstract}

Keywords: Phoomdi, Streptomyces sannanensis SU118, Antibacterial potential, Minimum inhibitory concentration

\section{Background}

Microbial natural products are the origin of most of the antibiotics on the market today. There is an alarming scarcity of new antibiotics currently under development in the pharmaceutical industry. Still, microbial natural products remain the most promising source of novel antibiotics, although new approaches are required to improve the efficiency of the discovery process. Actinomycetes have provided important bioactive compounds of high commercial value and continue to be

\footnotetext{
*Correspondence: shantiks@rediffmail.com

${ }^{1}$ Institute of Bioresources and Sustainable Development, Sikkim Centre, DBT, Tadong, Gangtok 737102, Sikkim, India

Full list of author information is available at the end of the article
}

routinely screened for new bioactive substances [1,2]. It is generally accepted that the streptomycetes have a particular capacity to produce a large variety of different bioactive compounds that have a wide spectrum of activity [3]. It is reported that $45 \%$ of the presently known bioactive microbial metabolites were still isolated from various actinomycetales species, and the Streptomyces species produces 7600 compounds ( $74 \%$ of all actinomycetales), while the rare actinomycetes represent $26 \%$, altogether 2500 compounds [4]. These organisms produce perhaps the most diverse and most unique, unprecedented, sometimes very complicated compounds exhibiting excellent antimicrobial potency and usually low toxicity [4]. The metabolic diversity of the actinomycetes is due to its 
extremely large genome, which has hundreds of transcription factors that control gene expression, allowing them to respond to specific needs [5]. Streptomyces sp. strain 201 endowed with novel antibiotic property has been isolated from tea garden soil [6]. Antimicrobial potentiality of salttolerant and alkaliphilic strain, Streptomyces tanashiensis A2D has also been reported by Singh et al. [7]. A new antiherpetic agent, fattiviracin has been isolated from Streptomyces microflavus [8]. These recent examples from the literature highlights the fact that despite extensive exploration of the actinomycetes for their antimicrobial products in the past, the search for novel molecules having unique therapeutic properties continues to be an active area of research. In the course of screening for new antibiotics, several studies are oriented towards isolation of new Streptomyces species from different habitats. Although soils have been screened by many workers for the past many decades, only a small fraction of actinomycetes have been discovered [9]. Actinomycetes from unexplored habitats have gained considerable attention in recent years for the production of bioactive metabolites.

The expanding list of novel microorganisms and the products derived from poorly explored areas of the world like Jordan [10], Antarctica [11] and certain biotope of Manipur [7] suggest that a careful exploration of new habitats might continue to be useful. The isolation of these microorganisms that produce bioactive compounds is of great interest in the development of new molecules to fight against many pathogen especially with the emergence of antibiotic multi-resistant pathogens.

The present study is a part of our on-going and extensive screening being carried out in the hitherto unexplored habitats of North-East India, under Indo-Burma Biodiversity hot spot with a view to realize the bioresources and value they have to mankind. This communication deals with the isolation, characterization and antimicrobial potentiality of a new actinomycete strain identified as Streptomyces sannanensis SU118.

\section{Methods}

\section{Location and collection of soil sample}

Soil samples were collected at a depth of $10-15 \mathrm{~cm}$ from the upper surface of top soil from phoomdi in Loktak lake (latitude, $24^{0} 25^{\prime}-24^{\circ} 42^{\prime} \mathrm{N}$; longitude, $93^{\circ} 46^{\prime}-93^{\circ} 55^{\prime} \mathrm{E}$ ) of Manipur, which is the largest natural lake $\left(289 \mathrm{Km}^{2}\right)$ in eastern India, where a unique ecological condition prevails. Phoomdi (Manipuri word meaning floating mats of soil and vegetation) is a unique untapped habitat with heterogenous mass of soil, vegetation and organic matter in different stages of decay. Seven soil samples each of approximately $50 \mathrm{~g}$ were collected from the pristine site. Each sampling was carried out at least $5 \mathrm{~m}$ apart. The samples were placed in sterile plastic containers, which were tightly sealed and transported to the laboratory.

\section{Culture media}

Starch casein agar (SCA): Soluble starch, 10.0 g; casein, 0.3 g; $\mathrm{KNO}_{3}, 2.0$ g; $\mathrm{NaCl}, 2.0$ g; $\mathrm{K}_{2} \mathrm{HPO}_{4}, 2.0$ g; $\mathrm{MgSO}_{4} .7 \mathrm{H}_{2} \mathrm{O}, 0.05$ g; $\mathrm{CaCO}_{3}, 0.02$ g; $\mathrm{FeSO}_{4} .7 \mathrm{H}_{2} \mathrm{O}$, $0.01 \mathrm{~g}$; Agar, $20.0 \mathrm{~g}$; distilled water, 1,000 ml; $\mathrm{pH}$ 7.0. Actinomycetes Isolation Agar (AIA); HiMedia Laboratories Pvt. Limited, Mumbai, India\}: Sodium caseinate, 2.0 g; Asparagine, $0.1 \mathrm{~g}$; Sodium propionate, $4.0 \mathrm{~g}$; Dipotassium phosphate, $0.5 \mathrm{~g}$; Magnesium sulphate, $0.1 \mathrm{~g}$; Ferrous sulphate, $0.001 \mathrm{~g}$ and Agar $20.0 \mathrm{~g}$; distilled water, 1,000 ml; $\mathrm{pH}$ 7.0. Glucose Soyabean meal broth (GSB) containing Glucose, 10.0 g; Soyabean meal, $10.0 \mathrm{~g} ; \mathrm{NaCl}, 10.0 \mathrm{~g}$; $\mathrm{CaCO}_{3}, 1.0$ g; distilled water, $1,000 \mathrm{ml}$ and $\mathrm{pH}$ adjusted to 7.0 was used as the production medium.

\section{Test microorganisms}

The test bacterial strains used for screening of antimicrobial activity were procured from microbial type culture collection (MTCC) and Gene Bank of the Institute of Microbial Technology (IMTECH), Chandigarh, India and are: Bacillus subtilis MTCC 736, Bacillus circulans MTCC 8074, Bacillus megaterium MTCC 8075, Staphylococcus aureus MTCC 96, Micrococcus luteus MTCC 2987, Mycobacterium phlei MTCC 1724, Mycobacterium smegmatis MTCC 6, Escherichia coli MTCC 739, Klebsiela pneumoniae MTCC 3040, Pseudomonas aeruginosa MTCC 2453. Apart from these one clinical isolate of Staphylococcus aureus obtained from Down Town Hospital Ltd., Guwahati, Assam, India was also used as test pathogen during the investigation.

\section{Isolation of the actinomycete strain}

During the course of screening for antibiotics from actinomycetes of Loktak habitats, the strain SU118 was isolated by serial dilution technique using SCA medium [12] by incubating at $28^{\circ} \mathrm{C}$ for 10 days from the soil sample collected from phoomdi in Loktak lake of Manipur, India. The pure culture of the isolate was obtained by repeated streaking on SCA plates. The pure isolate was transferred to SCA slants and preserved at $4^{\circ} \mathrm{C}$ for further use.

\section{Identification of the actinomycete strain}

The identification of the strain SU118 was carried out on the basis of the cultural characteristics, morphological, biochemical characteristics, through the courtesy of MTCC and Gene Bank of IMTECH, Chandigarh, India and also by the 16S rRNA gene sequencing carried out through the courtesy of National Centre for Cell Science, Pune, India.

\section{Construction of phylogenetic tree}

The sequenced 16S rRNA gene of the strain SU118 was aligned with the nucleotide sequences of Streptomyces 
genera in GenBank database using BLAST [13]. Sequences with more than 98\% homology were considered for molecular taxonomy analysis. Multiple alignments of $16 \mathrm{~S}$ rRNA nucleotide sequences in this study and sequences from GenBank database was performed with CLUSTAL W program [14]. A phylogenetic tree was generated using neighbor-joining method [15] with bootstrap testing [16] of 1,000 replicates, in MEGA6 [17].

\section{Morphological, cultural, physiological and biochemical characteristics}

The morphological characteristics were studied by using cover slip method in which the culture was transferred to the base of cover slips buried in SCA medium [18] and incubated at $28^{\circ} \mathrm{C}$ for seven days. The morphology of spore bearing hyphae with entire spore chain was then studied as described in Bergey's manual [19]. Carbohydrate utilization was determined by growth on carbon utilisation medium (International Streptomyces Project 9) [20] supplemented with $1 \%$ carbon source at $28^{\circ} \mathrm{C}$. Temperature range, $\mathrm{pH}$ range and $\mathrm{NaCl}$ tolerance for growth was determined on inorganic salt starch agar medium (ISP 4) by growing at different temperatures $\left(20-42^{\circ} \mathrm{C}\right), \mathrm{pH}(5-10)$ and $\mathrm{NaCl}$ concentration $(1-5 \% \mathrm{NaCl})$ respectively. Hydrolysis of starch, Liquefaction of gelatin and other biochemical tests were evaluated by following the methods of Gordon et al. [21]. Reduction of nitrate and production of melanoid pigment were determined by the method of ISP [22] Determination of LL-Diaminopimelic acid (L-DAP) and sugar pattern were carried out according to Becker et al. [23] and Lechevalier and Lechevalier [24]. All the results were recorded after seven days of incubation.

\section{Determination of antimicrobial potential of strain SU118 Spot inoculation on agar medium}

The antimicrobial activity was studied primarily by spot inoculation technique on agar medium as reported by Singh et al. [12]. The isolate SU118 was spot inoculated on SCA, the petri plates were incubated at $28^{\circ} \mathrm{C}$ for seven days and then inverted for 40 minutes over chloroform in fumehood. Colonies were then covered with a $0.6 \%$ agar layer of nutrient agar (NA) previously seeded with bacterial suspension of $1.5 \times 10^{8}$ colony forming units (CFU/spores)/ml in sterile normal saline [25] of the target bacterial strains and then incubated at $37^{\circ} \mathrm{C}$ for $24 \mathrm{~h}$. The zone of inhibition of growth of the test microorganisms around the actinomycete isolate SU118 was observed after incubation. S. aureus MTCC 96 was more sensitive to the antimicrobial agent; hence further studies were carried out with it.

\section{Antimicrobial agent production in liquid medium}

After preliminary testing for its antimicrobial potentiality, the isolate SU118 was further studied for the production of antimicrobial agent in liquid medium in shake flask condition. The effect of culture media on production of antimicrobial agent was examined by taking different liquid media such as Starch casein broth, Actinomycetes broth, Nutrient broth and GSB. A homogenous bacterial suspension $(0.2$ O.D measure at $600 \mathrm{~nm})$ of the isolate SU118 in $0.05 \%$ Tween 20 was prepared by taking inoculum from seven days old culture grown on SCA plate at $28^{\circ} \mathrm{C}$. Five $\mathrm{ml}$ of this suspension was inoculated into $100 \mathrm{ml}$ of each liquid media contained in $250 \mathrm{ml}$ Erlenmeyer flask and incubated at $28^{\circ} \mathrm{C}$ in a shaking incubator maintained at $150 \mathrm{rpm}$ for seven days. After incubation each culture broths were centrifuged at $10,000 \times \mathrm{g}$ (Sorvall Biofuge Primo $\mathrm{R})$ for 20 minutes at room temperature. The cell free supernatants were tested for extracellular antimicrobial activity by standard agar well diffusion method [26] against S. aureus MTCC 96, the most sensitive test organism in preliminary screening. Nutrient agar plates were inoculated with $0.2 \mathrm{ml}$ of overnight culture of $S$. aureus suspension containing $1.5 \times 10^{8}$ cells as mentioned above and uniformly spread out with the help of sterile glass spreader. Agar wells $(6 \times 4 \mathrm{~mm})$ were prepared by scooping out the medium with a sterile cork borer. The supernatant culture broth of each medium were then administered to the wells separately and incubated at $37^{\circ} \mathrm{C}$ for $24 \mathrm{~h}$. Antimicrobial activity was determined by measuring the inhibition zone diameter (in $\mathrm{mm}$ ) of S. aureus MTCC 96 around the well after incubation. Each experiment was conducted in three replicates and the mean value of inhibition zone diameter was calculated. Uninoculated broth medium added to the wells were taken as control. Among the different liquid media tried, GSB was found to be the best medium for antimicrobial agent production by the isolate SU118; hence GSB was used as production medium for further studies.

\section{Effect of temperature, $\mathrm{pH}$ and incubation period on growth and production of antimicrobial agent}

The effect of temperature on growth and production of antimicrobial agent was studied on GSB at different temperatures $\left(25,28,31,34\right.$ and $\left.37^{\circ} \mathrm{C}\right)$ at $\mathrm{pH} 7$. Five $\mathrm{ml}$ of spore suspension of isolate SU118 was inoculated into $100 \mathrm{ml}$ of GSB contained in $250 \mathrm{ml}$ Erlenmeyer flask and incubated in a shaking incubator maintained at $150 \mathrm{rpm}$ for seven days. The antimicrobial activity was evaluated against $S$. aureus MTCC 96 by agar well diffusion method in the similar manner as mentioned above. Similarly, the effect of $\mathrm{pH}$ on the production of antimicrobial agent was studied at different $\mathrm{pH}$ (5-9) using GSB by incubating at $28^{\circ} \mathrm{C}$ for seven days. The effect of incubation period on the production of antimicrobial agent was also studied in the similar way as above by incubating for different days $(1-10)$ at $28^{\circ} \mathrm{C}$ using GSB at $\mathrm{pH} 7$. 


\section{Estimation of growth}

The biomass from the culture filtrate separated by means of centrifugation was transferred to a pre-weighed dry filter paper using a clean spatula and then placed in an oven at $50^{\circ} \mathrm{C}$ overnight to reach a fixed weight. Growth in terms of biomass accumulation was expressed as $\mathrm{mg} / \mathrm{ml}$ of culture medium.

\section{Specific rate of product formation (qp)}

The specific rate of production of the antimicrobial agent (qp) was calculated according to the following equation:

$$
\mathrm{qp}=1 / \mathrm{X}(\mathrm{dp} / \mathrm{dt})
$$

Where $\mathrm{X}$ is the biomass concentration $(\mathrm{mg} / \mathrm{ml}), \mathrm{p}$ is antimicrobial agent concentration and $t$ is time respectively. The derivative $\mathrm{dp} / \mathrm{dt}$ was calculated according to the method proposed by Le Duy and Zajic [27].

\section{Extraction, purification and bioassay of the metabolite}

The culture broth of the isolate SU118 grown on GSB for 7 days at $28^{\circ} \mathrm{C}$ in a shaking incubator (150 rpm) was centrifuged at $10,000 \times \mathrm{g}$ (Sorvall Biofuge Primo R) for 20 minutes at room temperature. The crude bioactive metabolite produced in liquid culture medium by the isolate SU118 was extracted from the supernatant obtained by manual shaking thrice with equal volume of ethyl acetate (1:1) in a separating funnel. The solvent layer was collected and then evaporated under vacuum in a rotary evaporator (Buchi R-114, Germany) maintained at $40^{\circ} \mathrm{C}$ water bath and the crude metabolite thus obtained was subjected to partial purification. Purification of this crude metabolite was carried out by thin layer chromatography (TLC) technique on silica gel (Merck Ltd.) using hexane-ethyl acetate (Merck Ltd.) gradient $(1: 1 \rightarrow$ 1:3) as running solvent system. TLC purified fractions were recovered and antimicrobial activity was tested by agar well diffusion method against all the test microorganisms to find out the active metabolite among the different fractions. Each fraction was dissolved in 10\% dimethyl sulfoxide (DMSO) to get a concentration of $1 \mathrm{mg} / \mathrm{ml}$. From this $100 \mu \mathrm{l}$ were loaded in the agar wells prepared on the microbial bioassay plates as mention above. Wells filled with 10\% DMSO solution served as control. The Petri plates were incubated at $37^{\circ} \mathrm{C}$ for $24 \mathrm{~h}$. The inhibition zone diameter against the test microorganisms was recorded. Three replicates were maintained in each case.

\section{Minimum inhibitory concentration (MIC)}

MIC was determined according to Boruwa et al. [28] by adding an inoculum size of $3 \times 10^{5}$ colony forming units (cfu) $/ \mathrm{ml}$ of test microorganisms to $5 \mathrm{ml}$ of nutrient broth in different test tubes. Serial dilutions of the active metabolite (concentration ranging from $10 \mu \mathrm{g}$ to $0.25 \mu \mathrm{g} / \mathrm{ml}$ ) were added at the same time separately in the respective tube. MIC of the active metabolite against the bacterial test organisms was determined after $48 \mathrm{~h}$ of incubation by removing $10 \mu \mathrm{l}$ of the contents from each tube and spreading them onto NA plates. Each set of experiment was carried out in three replicates. Growth of the test microorganisms were observed after $24 \mathrm{~h}$ of incubation at $37^{\circ} \mathrm{C}$. In the similar way MIC of known antibiotic penicillin was also carried out as a standard for comparison. MIC is defined as the lowest concentration required to inhibit any visible growth.

\section{Determination of rate of kill}

In vitro assays for the rate of killing bacteria by the antimicrobial agent were carried out using a modified plating technique of Eliopoulos and Eliopoulos [29] and Eliopoulos and Moellering [30]. The antimicrobial agent was incorporated into $10 \mathrm{ml}$ Mueller Hinton broth in McCartney bottles at 1/2 MIC, $1 \times \mathrm{MIC}$, and $2 \times$ MIC. Two controls, one Mueller Hinton broth without the antimicrobial agent inoculated with test organisms and Mueller Hinton broth incorporated with the antimicrobial agent at the test concentrations without the test organisms, were included. Inoculums density, approximately $3 \times 10^{5} \mathrm{cfu} / \mathrm{ml}$ further verified by total viable count, was used to inoculate $10 \mathrm{ml}$ volumes of both test and control bottles. The bottles were incubated at $37^{\circ} \mathrm{C}$ on an orbital shaker at $120 \mathrm{rpm}$. A $100 \mu \mathrm{l}$ aliquot was removed from the culture medium at 0,4 , and $8 \mathrm{~h}$ for the determination of $\mathrm{cfu} / \mathrm{ml}$ by the plate count technique [31] by plating out $25 \mu \mathrm{l}$ of each of the dilutions. The problem of antimicrobial agent carryover was addressed by dilution as described previously by Pankuch et al. [32]. After incubating at $37^{\circ} \mathrm{C}$ for $24 \mathrm{~h}$, emergent bacterial colonies were counted, $\mathrm{cfu} / \mathrm{ml}$ calculated, and compared with the count of the culture control without the antimicrobial agent. Each experiment was performed in duplicate and mean value obtained. The results were expressed as negative or positive $\log _{10}$ values according to Baltch et al. [33].

\section{Statistical analysis}

Statistical analysis was carried out by calculating the means and standard deviations of the results. Duncans multiple range test (DMRT) was done to compare that the sample means were significantly different from each other at a significant level of $\mathrm{P}>0.001$ [34].

\section{Results}

\section{Characterization and taxonomy of the strain}

The actinomycetes strain SU118 isolated from soil samples of phoomdi in Loktak Lake of Manipur, India 
is a Gram-positive filamentous bacterium. The vegetative mycelium showed cream-light brown colour while the aerial mycelium showed light gray colour. The culture, when examined by light microscope $(100 \times)$ have straight to flexuous sporophores arising from the aerial mycelium and may be placed in the RectusFlexibilis (RF) group of Streptomyces species [35]. The strain SU118 could grow up to $40^{\circ} \mathrm{C}$ and $\mathrm{pH} 9$ with $3 \% \mathrm{NaCl}$ concentration. LL-diaminopimelic acid (L-DAP) was present in the cell wall but no characteristic sugar. The strain SU118 could utilize glucose, arabinose, mannitol, xylose, meso-inositol, raffinose, rhamnose, salicin, sucrose, galactose and fructose as the carbon source without the production of acid. The morphological, physiological and biochemical characteristics of the strain SU118 is shown in Table 1. The 16S rRNA gene sequence of the strain SU118 was compared with the nucleotide sequences of other Streptomyces strains from the NCBI GenBank database. The phylogenetic tree generated on the basis of 16S rRNA gene sequence of the strain SU118 and the nucleotide sequences from closely related Streptomyces strains using neighbor-joining method is presented in Figure 1. The strain has got maximum $16 \mathrm{~S}$ rRNA gene sequence homology (99\%) with S. sannanensis strain HBUM174756. Therefore, on the basis of morphological, physiological, biochemical and analysis of the $16 \mathrm{~S}$ rRNA gene sequence, the new isolate SU118 was designated as S. sannanensis strain SU118. The 16S rRNA gene partial sequence of the isolate SU118 has been deposited in the GenBank database under the accession number EU278596. The phylogenetic tree of the strain SU118 has been deposited in TreeBASE repository with the submission ID 16506. Further the information associated with the phylogenetic placement of the strain SU118 is available in http://treebase.org/treebase-web/search/study/ summary.html?id=16506. The identity of the isolate was further confirmed by the Microbial Type Culture Collection and Gene Bank (MTCC) of the Institute of Microbial Technology, Chandigarh, India. The culture has been deposited in MTCC, an International Depository Authority and the accorded accession number is MTCC-7041.

\section{Antimicrobial potential of the strain SU118}

During the course of screening of actinomycetes possessing antimicrobial activity, it was observed that $S$. sannanensis SU118 was highly antagonist to Gram-positive bacteria including one clinical isolate of $S$. aureus while it does not have any inhibitory effect against any of the tested Gram-negative bacteria (Table 2). S. aureus MTCC 96 was the most sensitive to the antimicrobial agent; hence it was taken as test organism for further studies. Among the different liquid media studied for antimicrobial agent production in shake flask condition, GSB was found to be most suitable for growth as well as synthesis of
Table 1 Morphological, physiological and biochemical characteristics of Streptomyces sannanensis SU118

\begin{tabular}{ll}
\hline Properties & Result \\
\hline Morphological characteristics & \\
Cell shape & Mycelial \\
Sporophore morphology & Rectus- Flexibilis (RF) \\
Aerial mycelium colour & Light gray \\
Substrate mycelium colour & Cream-light brown
\end{tabular}

\section{Physiological characteristics}

Growth under anaerobic condition

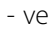

Acid-fast reaction

- ve

Production of melanoid pigment

- ve

Temperature range for growth

+ ve

$25-40^{\circ} \mathrm{C}$

Optimum temperature for growth

$28^{\circ} \mathrm{C}$

$\mathrm{pH}$ range for growth

$5-9$

Optimum $\mathrm{pH}$ for growth

Growth on Mc Conkey agar

7

- ve

$\mathrm{NaCl}$ tolerance

$3 \%$

Biochemical characteristics

Gram reaction

+ ve

Catalase production

- ve

Oxidase production

- ve

Urease production

- ve

Hydrogen sulfide production

Nitrate reduction

- ve

- ve

Gelatin liquefaction

- ve

Methyl red test

- ve

Vogues proskauer test

Indole production test

Citrate utilization test

Starch hydrolysis

Casein hydrolysis

- ve

- ve

- ve

+ ve

- ve

Acid production from

Glucose

- ve

Arabinose

- ve

Mannitol

Xylose

Meso-inositol

Raffinose

- ve

- ve

- ve

Rhamnose

- ve

Salicin

- ve

Sucrose

- ve

Galactose

- ve

Fructose

Cell-wall amino acids

- ve

Cell-wall sugars

LL-Diaminopimelic aid

No diagnostic 


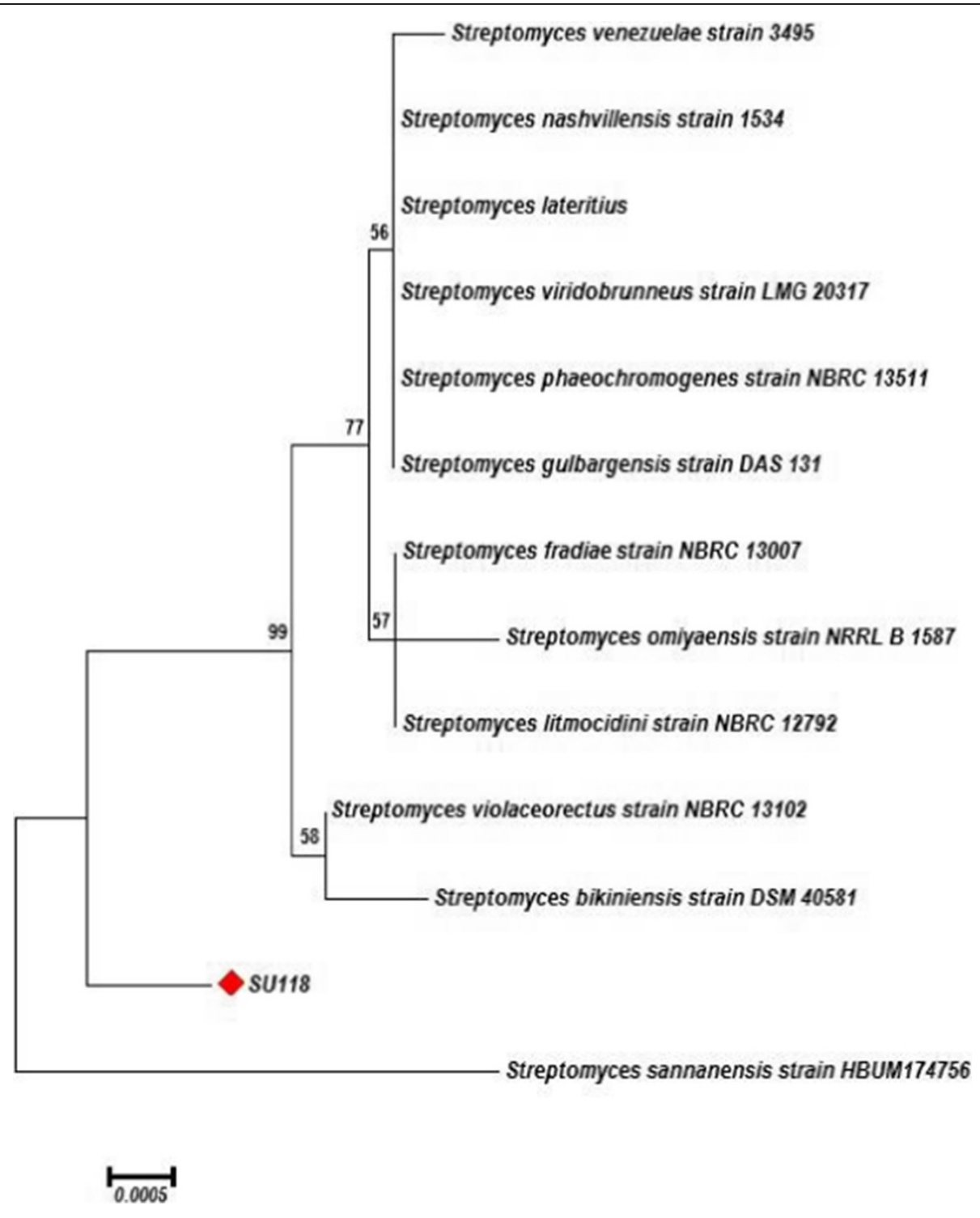

Figure 1 Phylogenetic tree based on 16S rRNA gene sequences from the strain SU118 and other Streptomyces species.

antimicrobial agent by S. sannanensis SU118 (Figure 2). It was observed that the culture filtrate of $S$. sannanensis SU118 grown on GSB exhibited maximum inhibition zone diameter against $S$. aureus MTCC 96 followed by the culture filtrate grown on SC broth, while lowest activity was seen with the one grown on NB.

Effect of cultural parameters on growth and production of antimicrobial agent

The environmental requirements and cultural conditions for growth and production of antimicrobial agent by S. sannanensis SU118 has been studied on GSB in shake flask condition. The strain S. sannanensis SU118 showed a narrow range of incubation temperature for relatively good growth and antibiotic production. $28^{\circ} \mathrm{C}$ was found to be optimum for highest growth as well as maximum antimicrobial agent production by the strain (Figure 3). In terms of its optimum temperature for growth, the organism appeared to be mesophilic in nature. The highest growth as well as maximum antimicrobial agent production was obtained at $\mathrm{pH} 7$. Poor growth was evident at $\mathrm{pH}$ values below and above neutral (Figure 4). Incubation period up to seven days was found to be optimum for maximum growth as well as antimicrobial agent production by S. sannanensis SU118 (Figure 5). The highest value of specific rate of production of the antimicrobial agent (0.0046 day $\left.{ }^{-1}\right)$ was observed on $6^{\text {th }}$ day (Figure 6). 
Table 2 Inhibition zone diameter and minimum inhibitory concentration of the active compound $\left(R_{f}\right.$ value $\left.\mathbf{0 . 5 6}\right)$ produced by Streptomyces sannanensis SU118

\begin{tabular}{llll}
\hline Test microorganisms & Inhibition zone diameter $(\mathbf{m m}) ¥$ & MIC $(\boldsymbol{\mu g} / \mathbf{m l})$ & MIC of penicillin $(\boldsymbol{\mu g} / \mathbf{m l})$ \\
\hline Bacillus subtilis MTCC 736 & $25 \pm 1.0$ & 2.0 & 0.5 \\
Bacillus circulans MTCC 8074 & $23 \pm 1.2$ & 3.0 & 0.5 \\
Bacillus megaterium MTCC 8075 & $26 \pm 1.5$ & 2.0 & 0.5 \\
Staphylococcus aureus MTCC 96 & $31 \pm 0.9$ & 0.5 & 0.25 \\
Staphylococcus aureus (Clinical isolate) & $30 \pm 0.9$ & 0.5 & 0.25 \\
Micrococcus luteus MTCC 2987 & $25 \pm 1.3$ & 2.0 & 0.5 \\
Mycobacterium phlei MTCC 1724 & $25 \pm 1.0$ & 2.0 & 0.5 \\
Mycobacterium smegmatis MTCC 6 & $21 \pm 0.5$ & 3.0 & 1.0 \\
Escherichia coli MTCC 739 & & ND & ND \\
Klebsiela pneumoniae MTCC 3040 & & ND & ND \\
Pseudomonas aeruginosa MTCC 2453 & & ND & ND
\end{tabular}

Note: Data express as mean \pm SD $(\mathrm{n}=3)$ " - " : No Inhibition Zone; $¥$ Concentration of the active compound: $1 \mathrm{mg} / \mathrm{ml}$; ND - Not determined.

Purification and bioactivity of the metabolite

The dark brown colored crude metabolite recovered by solvent extraction method using ethyl acetate was purified by TLC in a running solvent system of hexane and ethyl acetate in 1:3 ratio. Four fractions designated as A, B, C and $D$ (Figure 7 ) with different $R_{f}$ values recovered from TLC plates were dissolved in 10\% DMSO and bioassayed against the test microorganisms. The fraction $B$ with $R_{f}$ value 0.56 and $U V \lambda_{\max } 275.0 \mathrm{~nm}$ in ethyl acetate exhibits antimicrobial activity against all the Gram-positive bacteria tested while it does not affect Gram-negative bacteria (Table 2). Other fractions (A, C and D) did not show any activity against the test organisms. Hence the fraction $\mathrm{B}$ is considered as the active metabolite. The results indicated that $S$. aureus MTCC 96 was the most sensitive while $M$. smegmatis MTCC 6 was found to be least sensitive to the active metabolite obtained from $S$. sannanensis strain SU118. The quantitative efficacy of the active metabolite was estimated as MIC and it has got lowest MIC $(0.5 \mu \mathrm{g} / \mathrm{ml})$ against S. aureus MTCC 96 and $S$. aureus (Clinical isolate), whereas highest $(3.0 \mu \mathrm{g} / \mathrm{ml})$ was recorded against $M$. smegmatis MTCC 6 and B. circulans MTCC 8074 (Table 2). The active metabolite was soluble in ethyl acetate, hexane, chloroform and DMSO whereas sparingly soluble in water.

\section{Determination of rate of kill}

The results of time-kill assay are presented in Table 3. Data are presented in terms of the $\log _{10} \mathrm{cfu} / \mathrm{ml}$ change and are based on the conventional bactericidal activity

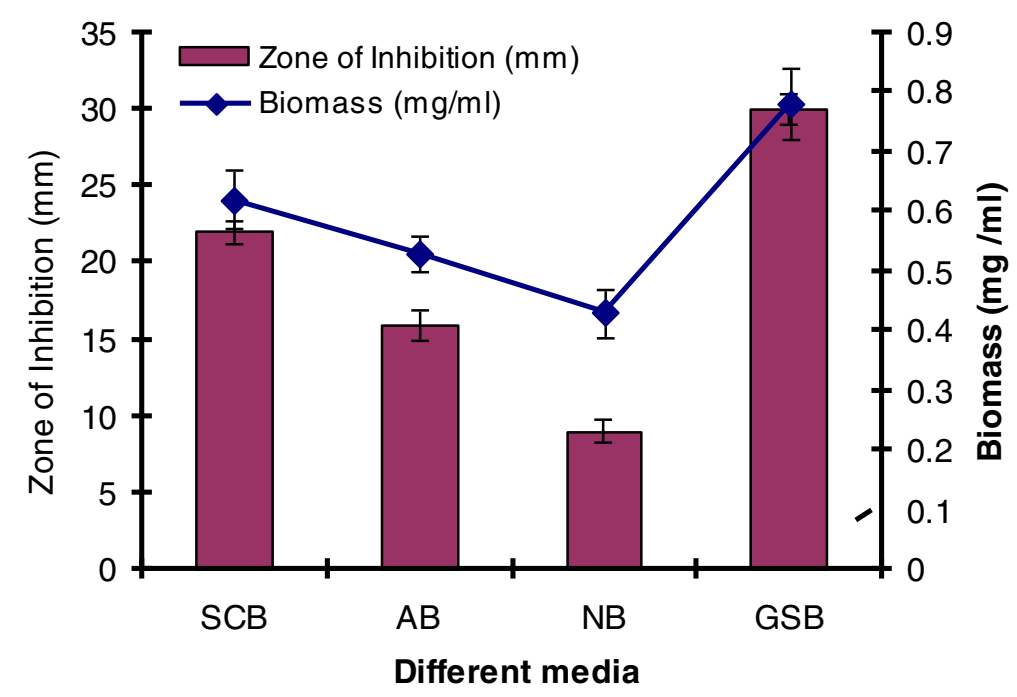

Figure 2 Effect of various culture media on growth and antimicrobial agent production by Streptomyces sannanensis SU118 (SCB- Starch casein broth; AB- Actinomycete broth; NB- Nutrient broth; GSB- Glucose soyabean meal broth). 


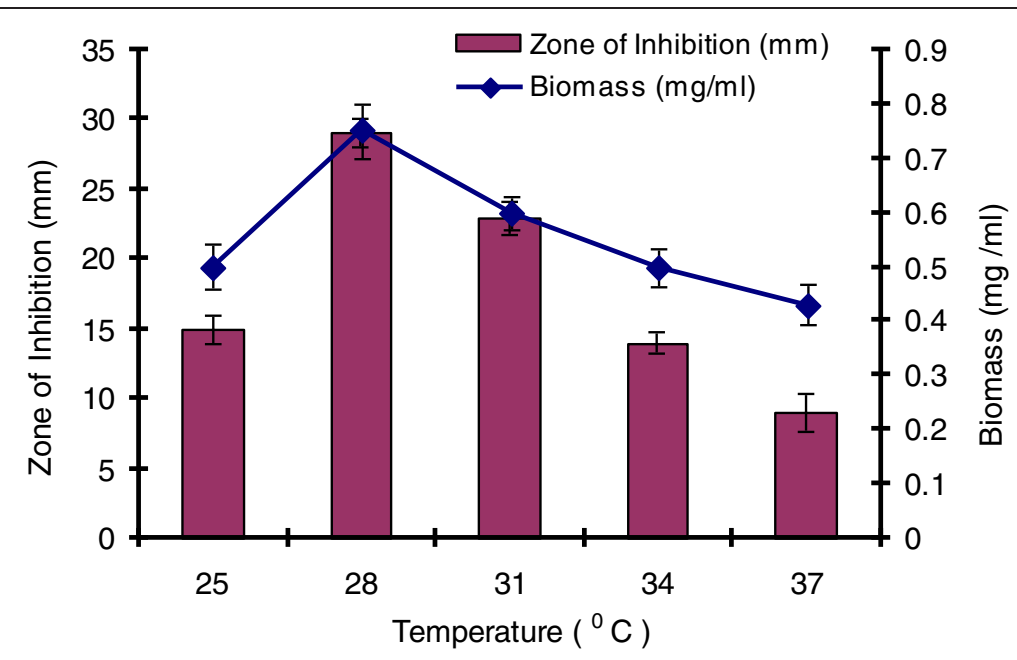

Figure 3 Effect of incubation temperature on growth and antimicrobial agent production by Streptomyces sannanensis SU118.

standard, that is, a $3 \log _{10} \mathrm{cfu} / \mathrm{ml}$ or greater reduction in the viable colony count relative to the initial inoculums according to Pankey and Sabath [36]. After $4 \mathrm{~h}$ of incubating the bacteria with the $1 \times$ MICs and $2 \times$ MICs, the average log reduction in the viable cell count ranged between 0.198 $\log _{10}$ and $1.218 \log _{10} \mathrm{cfu} / \mathrm{ml}$. After $8 \mathrm{~h}$ of incubation with these different concentrations, the average log reduction in the viable cell count ranged between $-2.075 \log _{10}$ and $0.891 \log _{10} \mathrm{cfu} / \mathrm{ml}$. The incubation of the bacteria for $4 \mathrm{~h}$ at $1 \times$ MICs resulted in the average log reduction of the viable cell count ranging between $0.959 \log _{10}$ and 1.218 $\log _{10} \mathrm{cfu} / \mathrm{ml}$, while after $8 \mathrm{~h}$ of incubation, the average $\log$ reduction ranged between $0.367 \log _{10}$ and 0.891 $\log _{10} \mathrm{cfu} / \mathrm{ml}$. The incubation of the bacteria for $4 \mathrm{~h}$ at $2 \times$ MICs resulted in the average log reduction of the viable cell count ranging between $0.198 \log _{10}$ and $0.487 \log _{10} \mathrm{cfu} / \mathrm{ml}$, while after $8 \mathrm{~h}$ of incubation, the average log reduction in the viable cell count ranged between $-2.075 \log _{10}$ and $-1.484 \log _{10} \mathrm{cfu} / \mathrm{ml}$. The greatest log reduction in cell density with the antimicrobial agent was observed in S. aureus MTCC $96\left(-2.075 \log _{10} \mathrm{cfu} / \mathrm{ml}\right)$ followed by $S$. aureus (Clinical isolate) $\left(-1.953 \log _{10} \mathrm{cfu} / \mathrm{ml}\right)$, while least log reduction in cell density was observed in M. smegmatis MTCC $6\left(-1.484 \log _{10} \mathrm{cfu} / \mathrm{ml}\right)$.

\section{Discussion}

Actinomycetes have been recognized as the potential producers of metabolites such as antibiotics, growth promoting substances for plants and animals, immunomodifiers, enzyme inhibitors and many other compounds of use to man. Isolation of new microbial species from hitherto unexplored areas and/or from extreme environments is one of the more efficient approaches for the development of potential novel bioactive metabolites [37,38]. The high proportion of strains producing antimicrobials from such environments may be associated with defensive or

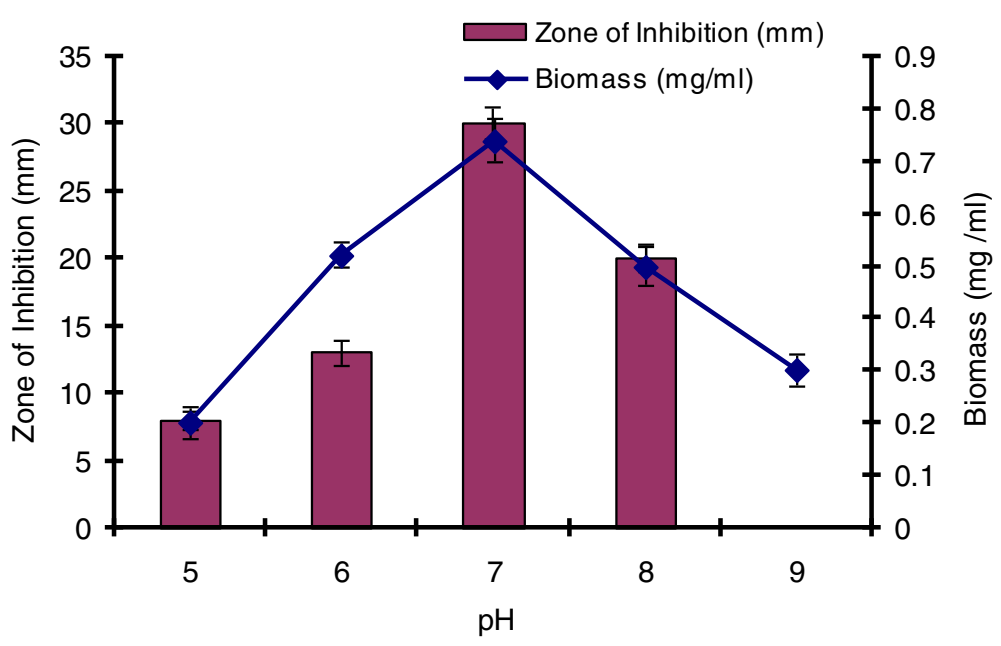

Figure 4 Effect of pH on growth and antimicrobial agent production by Streptomyces sannanensis SU118. 


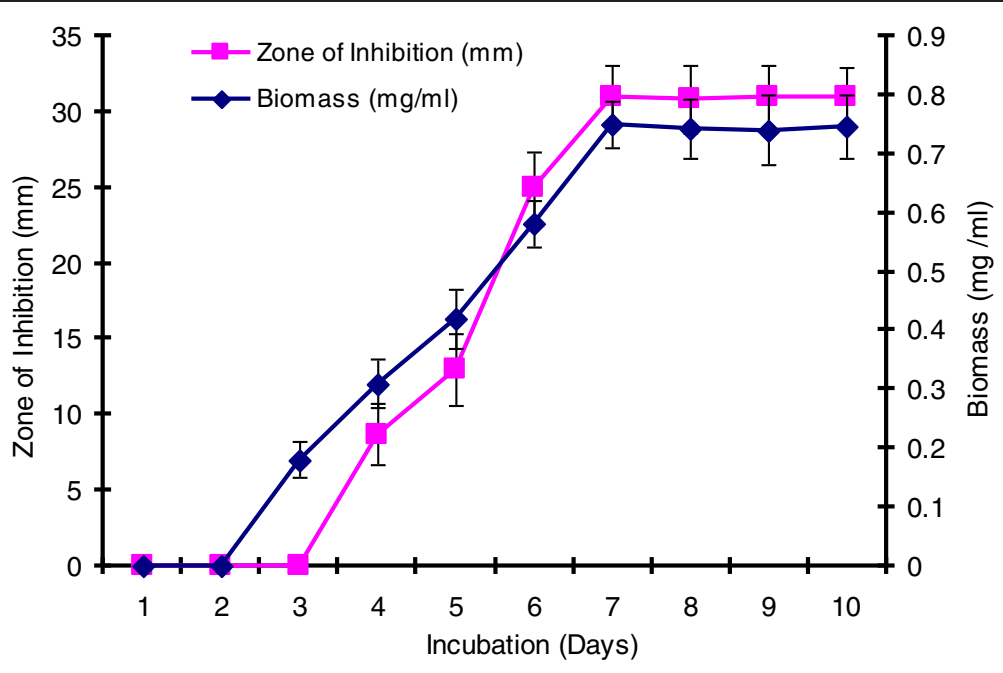

Figure 5 Effect of incubation period on growth and antimicrobial agent production by Streptomyces sannanensis SU118.

aggressive roles of the organisms for maintaining their ecological niche in such environments. Further, the thriving of microorganisms in such competitive environments is assumed that their metabolic compatibility is strongly influenced by natural selection [39]. With this perspective, an antimicrobial agent producing actinomycete strain SU118 was isolated from the phoomdi soil of Loktak lake in Manipur, India. The isolate has been characterized and identified as $S$. sannanensis strain SU118.

The antimicrobial activity of S. sannanensis SU118 was screened against various Gram-positive and Gram-negative organisms. The results showed that $S$. sannanensis SU118 secretes a narrow spectrum antimicrobial agent which could inhibit the growth of only Gram-positive bacteria. However, it did not affect the growth of Gram-negative organisms. Similar antimicrobial activity specific to Gram-positive bacteria has also been reported in $S$. aburaviensis strain Kut-8 [40]. The reason for differential sensitivity between Gram-positive and Gram-negative bacteria could be ascribed to the morphological differences between these microorganisms; Gram-negative bacteria have an outer polysaccharide membrane carrying the structural lipopolysaccharide components. This makes the cell wall impermeable to lipophilic compounds; the Gram-positive bacteria, on the other hand, will be

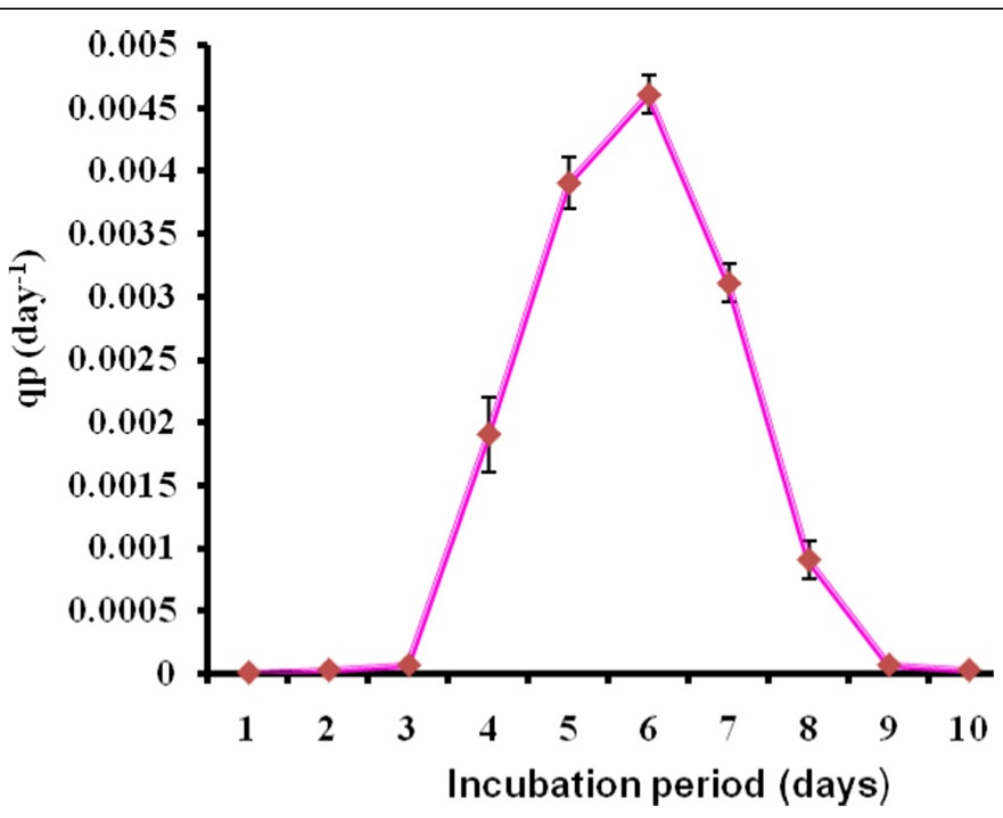

Figure 6 Specific rate of antimicrobial agent production (qp) by Streptomyces sannanensis SU118. 


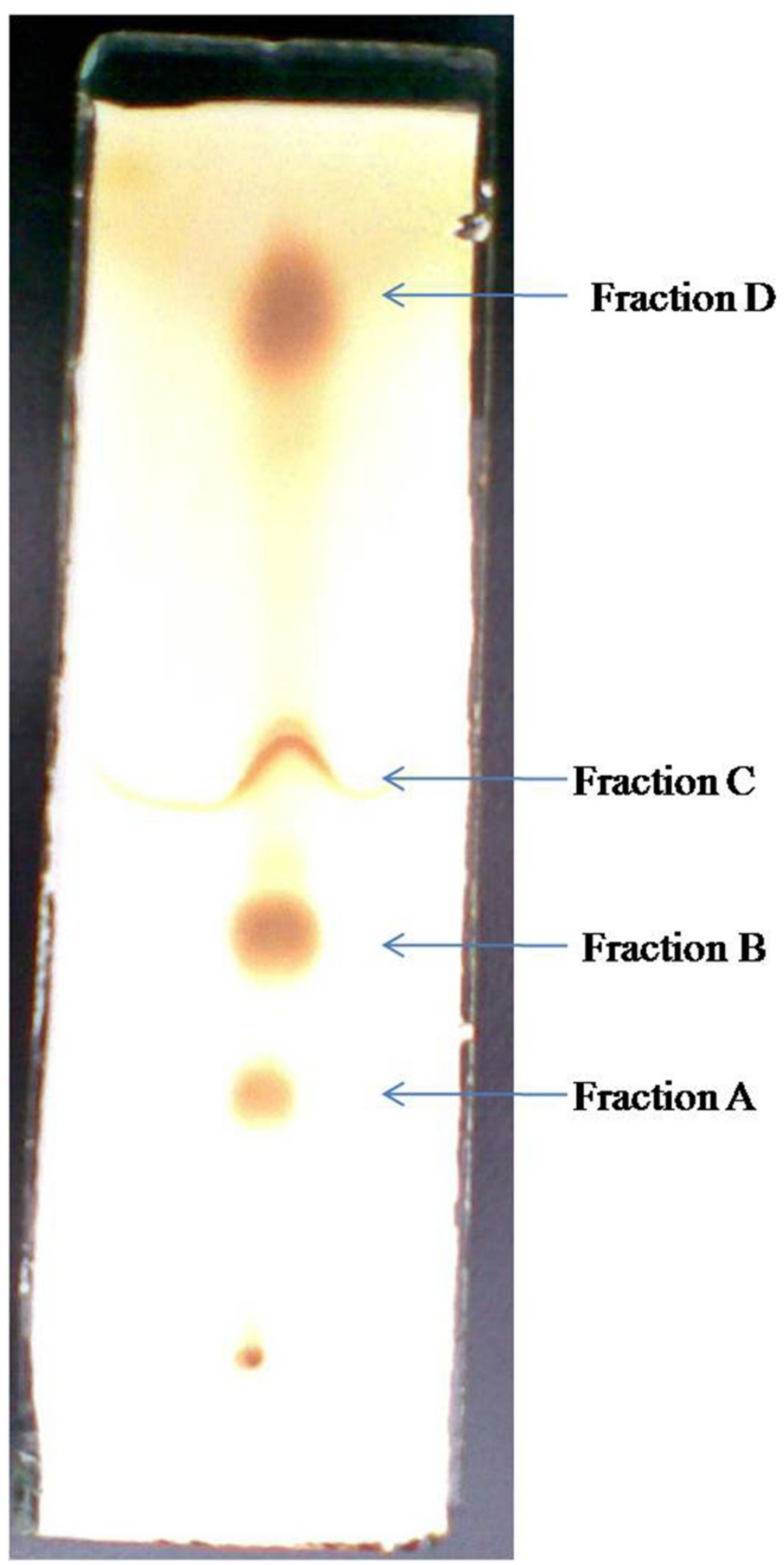

Figure 7 Thin layer chromatography plate showing the separation of bioactive compound (fraction B) obtained from Streptomyces sannanensis SU118. 
Table 3 In vitro time-kill assessment of the antimicrobial agent against the test microorganisms

\begin{tabular}{|c|c|c|c|c|c|c|c|c|c|}
\hline \multirow[t]{2}{*}{ Test bacterial strains } & \multicolumn{3}{|c|}{$\begin{array}{l}\log _{10} \text { Kill } \\
(1 / 2) \text { X MIC }\end{array}$} & \multicolumn{3}{|c|}{$\begin{array}{l}\log _{10} \text { Kill } \\
\text { MIC }\end{array}$} & \multicolumn{3}{|c|}{$\begin{array}{l}\log _{10} \text { Kill } \\
2 \text { X MIC }\end{array}$} \\
\hline & $\mathrm{Oh}$ & $4 \mathrm{~h}$ & $8 \mathrm{~h}$ & $\mathrm{Oh}$ & $4 \mathrm{~h}$ & $8 \mathrm{~h}$ & $\mathrm{Oh}$ & $4 \mathrm{~h}$ & $8 \mathrm{~h}$ \\
\hline Bacillus subtilis MTCC 736 & 2.381 & 3.131 & 4.213 & 2.364 & 1.165 & 0.507 & 2.286 & 0.365 & -1.776 \\
\hline Bacillus circulans MTCC 8074 & 2.456 & 3.233 & 4.336 & 2.478 & 1.213 & 0.578 & 2.346 & 0.389 & -1.501 \\
\hline Bacillus megaterium MTCC 8075 & 2.234 & 3.691 & 4.821 & 2.227 & 1.186 & 0.515 & 2.242 & 0.296 & -1.875 \\
\hline Staphylococcus aureus MTCC 96 & 2.487 & 2.756 & 3.251 & 2.491 & 0.959 & 0.367 & 2.475 & 0.198 & -2.075 \\
\hline Staphylococcus aureus (Clinical isolate) & 2.983 & 3.423 & 4.206 & 2.907 & 0.979 & 0.406 & 2.915 & 0.203 & -1.953 \\
\hline Micrococcus luteus MTCC 2987 & 2.169 & 2.792 & 3.042 & 2.127 & 1.146 & 0.723 & 2.217 & 0.401 & -1.637 \\
\hline Mycobacterium phlei MTCC 1724 & 2.291 & 2.813 & 3.112 & 2.251 & 1.187 & 0.811 & 2.252 & 0.431 & -1.576 \\
\hline Mycobacterium smegmatis MTCC 6 & 2.386 & 2.912 & 3.102 & 2.298 & 1.218 & 0.891 & 2.379 & 0.487 & -1.484 \\
\hline
\end{tabular}

more susceptible as they have only an outer peptidoglycan layer which is not an effective permeability barrier [41].

The study on the production of antimicrobial agent usually involves a search of a suitable culture medium. Among the four media tried, GSB was found to be the optimum medium for antimicrobial agent production by S. sannanensis SU118. It was evident from the finding that the antimicrobial agent production by $S$. sannanensis SU118 was positively affected by the nature and type of carbon and nitrogen sources in the medium. The results showed that antimicrobial agent production was higher in medium having glucose and soyabean meal as carbon and nitrogen source respectively. This result is quite comparable with S. griseocarneus, for which glucose was found to be suitable carbon source for the antibiotic production [42]. Considering the carbon source, simple sugar such as glucose, fructose, sucrose as sole carbon source enhanced growth as well as bioactive metabolite production rather than more complex carbons [43]. Our result is also in conformity with the findings of Singh et al. [7] for which soyabean meal proved to be suitable carbon source for antibiotic production by $S$. tanashiensis A2D. The results indicated the dependence of the antimicrobial agent synthesis on the medium constituents. In fact, it has been shown that the nature of carbon and nitrogen sources strongly affect antibiotic production in different organisms [44]. The strain S. sannanensis SU118 showed a narrow range of incubation temperature for relatively good growth and antimicrobial agent production. Highest growth and antimicrobial agent production was obtained at $28^{\circ} \mathrm{C}$. The temperature range adequate for good production of secondary metabolites is narrow, for example, $5 \sim 10$ degrees [45]. The maximum growth as well as highest antimicrobial activity by $S$. sannanensis SU118 was achieved at pH 7 while it does not exhibit any activity at $\mathrm{pH}$ 9. There are reports regarding the role of $\mathrm{pH}$ on the production of bioactive metabolite by microorganisms [46]. Incubation period upto seven days was found to be optimum for highest antimicrobial agent production by the strain SU118. Griffiths and Saker [47] reported that maximum secretion of bioactive metabolites by Cylindrospermopsis raciboskii was found to occur as cultures moved into the post-exponential phase of growth, while Egorov [48] postulated that maximum antimicrobial activity was attained after reaching the maximum value of the biomass. The results indicated that environmental factors and cultural conditions like incubation temperature, $\mathrm{pH}$ and incubation period were found to have profound influence on antimicrobial agent production by S. sannanensis SU118 as surveyed in streptomycetes by other investigator [49]. The result for the determination of specific rate of production of antimicrobial agent by the strain SU118 showed to be maximum on the sixth day $\left(0.0046\right.$ day $\left.{ }^{-} 1\right)$. The strain SU118 showed specific potential in antimicrobial agent production. Other observations on the specific rate of production of bioactive metabolite by different microorganism have also been reported [50,51].

The solvent extraction of the culture broth of $S$. sannanensis SU118 using ethyl acetate and subsequent purification led to the recovery of a potent antibacterial agent active against Gram-positive bacteria. Remya and Vijaykumar [52] have reported the antimicrobial potential of compound obtained from ethyl acetate extract of Streptomyces strain RM42. Similarly, the extraction of antibiotics has been carried out from streptomycetes by using various solvents including ethyl acetate and methanol [53,54].

The resultant effect of incubating the bacteria at $2 \times$ MICs was a significantly rapid reduction in the average log of the viable cells counts. This reduction is greater than the rate of kill observed in the test bacterial strains treated with the $1 \times$ MICs. The significant reduction in the cell counts between 4 and $8 \mathrm{~h}$ of incubation period acknowledged the fact that the antimicrobial agent was highly bactericidal seeing that the bacterial colonies were almost totally wiped out after incubating for $8 \mathrm{~h}$. On the contrary, there was a net growth of all the test bacterial strains treated with the 
$1 / 2 \times$ MICs of the antimicrobial agent. The growth inhibition and efficacy of the antimicrobial agent were observed to be concentration and time dependent producing distinct time-kill profiles for the tested bacterial strains.

Detection and identification of members of the genus Streptomyces are of great value because they provide a rich source of antibiotics. The emergence and dissemination of antibacterial resistance is well documented as a serious problem worldwide [55]. Smith et al. express that "The emergence of bacterial resistance threatens to return us to the era before the development of antibiotics" [56]. The perspective of rapid emergence of drug resistance among bacterial pathogens shows that the potencies of prevalent antibiotics are decreasing steadily, leading to reduced useful-period of drugs. This situation compounds the need for the investigation of new, safe and effective antimicrobials for replacement with invalidated antimicrobials or use in antibiotic rotation programs [57].

\section{Conclusions}

The strain SU118 showed a narrow spectrum of activity inhibiting only Gram-positive bacteria, when tested with crude culture filtrate and also with active metabolite $\left(R_{f}\right.$ value $\left.=0.56\right)$. The MICs of the antimicrobial agent against the test pathogens indicated the potent activity which highlights its prospective and could be a candidate in the generation of new antimicrobial agents and also throws a light towards the fight against drug resistant pathogens especially of the methicillin resistant Staphylococcus aureus (MRSA), since this particular isolate SU118 inhibits only the Gram positive bacteria. The findings of the present study showed that naturally occurring actinomycetes have a great potential to produce metabolite active against bacteria enabling discovery of new antibiotics and hence merit future studies. Further ongoing detailed characterization and structure elucidation of the bioactive metabolite may be a new entity reported from this unique untapped ecological niche.

\section{Competing interests}

The authors declare that they have no competing interest.

\section{Authors' contribution}

LSS: performed the entire experiment and prepared the manuscript. HS: assisted LSS in conducting the experiment and also in preparing the manuscript. NCT: Supervised and coordinated the study. All authors have duly checked and approved the manuscript before submission.

\section{Acknowledgements}

The authors thank the Department of Biotechnology (DBT), Government of India, New Delhi for the financial assistance and deep appreciation is expressed to Dr. Yogesh S. Shouche, Scientist, National Center for Cell Science, Pune, India for $16 \mathrm{~S}$ rRNA gene sequencing of the strain. We are very grateful to anonymous reviewers and the editor of BMC Microbiology for their kind comments and suggestions to improve this manuscript.

\section{Author details}

'Institute of Bioresources and Sustainable Development, Sikkim Centre, DBT, Tadong, Gangtok 737102, Sikkim, India. ${ }^{2}$ Institute of Bioresources and Sustainable Development, DBT, Takyelpat Institutional Area, Imphal 795001, Manipur, India.

Received: 23 October 2013 Accepted: 28 October 2014

Published online: 19 November 2014

\section{References}

1. Takahashi Y: Exploitation of new microbial resources for bioactive compounds and discovery of new actinomycetes. Actinomycetology 2004, 18:54-61.

2. Meena B, Rajan LA, Vinithkumar NV, Kirubagaran R: Novel marine actinobacteria from emerald Andaman \& Nicobar Islands: a prospective source for industrial and pharmaceutical byproducts. BMC Microbiol 2013, 13:145-161.

3. Zin NM, Sarmin NIM, Ghadin N, Basri DF, Sidik NM, Hess WM, Strobel GA: Bioactive endophytic streptomycetes from the Malay Peninsula. FEMS Microbiol Lett 2007, 274:83-88.

4. Berdy J: Bioactive microbial metabolites; a personal view. J Antibiot 2005, 58(1):1-26.

5. Goshi K, Uchida T, Lezhava A, Yamasaki M, Hiratsu K, Shinkawa H, Kinashi H: Cloning and analysis of the telomere and terminal inverted repeat of the linear chromosome of Streptomyces griseus. J Bacteriol 2002, 184:3411-3415.

6. Bordoloi G, Kumari B, Guha A, Bordoloi MJ, Yadav RNS, Roy MK, Bora TC: Isolation and structure elucidation of a New antifungal and antibacterial antibiotic produced by Streptomyces sp. 201. Biosci Biotech Biochem 2001, 65(8):1856-1858.

7. Singh LS, Mazumder S, Bora TC: Optimisation of process parameters for growth and bioactive metabolite produced by a salt-tolerant and alkaliphilic, Streptomyces tanashiensis strain A2D. J Myc Med 2009, 19:225-233.

8. Uyeda M: Metabolites produced by actinomycetes - antiviral antibiotics and enzymes inhibitors. Yakugaku Zasshi 2004, 128:469-479.

9. Baltz RH: Antibiotic discovery from actinomycetes: will a renaissance follow the decline and fall? SIM News 2005, 55:186-196.

10. Saadoun I, Gharaibeh R: The Streptomyces flora of Badia region of Jordan and its potential as a source of antibiotic-resistant bacteria. J Arid Environ 2003, 53:365-371.

11. Nedialkova D, Naidenova M: Screening the antimicrobial activity of actinomycetes strains isolated from Antarctica. J Cult Collect 2004-2005, 4:29-35.

12. Singh LS, Baruah I, Bora TC: Actinomycetes of loktak habitat: isolation and screening for antimicrobial activities. Biotechnology 2006, 5:217-221.

13. Altschul SF, Thomas LM, Alejandro AS, Zhang J, Zhang Z, Miller W, Lipman DJ: Gapped BLAST and PSI-BLAST: a new generation of protein database search programs. Nucleic Acids Res 1997, 25:3389-3402.

14. Thompson JD, Higgin DG, Gibson TJ: CLUSTAL W: improving the sensitivity of progressive multiple sequence alignment through sequence weighting, position-specific gap penalties and weight matrix choice. Nucl Acid Res 1994, 22:4673-4680.

15. Saitou N, Nei M: The neighbor-joining method: a new method for reconstructing phylogenetic trees. Mol Biol Evol 1987, 4:406-425.

16. Felsenstein J: Confidence limits on phylogenies: an approach using the bootstrap. Evolution 1985, 39:783-789.

17. Tamura K, Stecher G, Peterson D, Filipski A, Kumar S: MEGA6: molecular evolutionary genetics analysis version 6.0. Mol Biol Evol 2013, 30:2725-2729.

18. Williams ST, Cross T: Isolation, Purification, Cultivation and Preservation of Actinomycetes. In Methods in Microbiology, Volume 4. Edited by Norris JR, Ribbons DW. London: Academic Press; 1971:295-334.

19. Locci R: Streptomycetes and Related Genera. In Bergey's Manual of Systematic Bacteriology, Volume 4. Edited by Williams ST. Baltimore: Williams and Wilkins Company; 1989:2451-2469.

20. Pridham TG, Gottlieb D: The utilization of carbon compounds by some actinomycetales as an aid for species determination. J Bacteriol 1948, 56:107-114.

21. Gordon RE, Barnett DA, Handerhan JE, Pang CH: Nocardia coeliaca, Nocardia autotrophica and the Nocardia strain. Int I Syst Bacteriol 1974 24:54-63. 
22. Shirling EB, Gottlieb D: Methods for characterization of Streptomyces species. Int J Syst Bacteriol 1966, 16:313-340.

23. Becker B, Lechevalier MP, Gordon RE, Lechevalier HA: Rapid differentiation between Nocardia and Streptomyces by paper chromatography of whole-cell hydrolysates. J App/ Microbiol 1964, 12:421-423.

24. Lechevalier MP, Lechevalier $\mathrm{H}$ : Chemical composition as a criterion in the classification of aerobic actinomycetes. Int I Syst Evol Microbiol 1970, 20:435-443.

25. Forbes BA, Sahm DF, Weissfeld AS, Trevino EA: Bailey and Scott's Diagnostic Microbiology. St. Louis, Missouri: Mosby Co; 1990:171-194.

26. Grammer A: Antibiotic Sensitivity and Assay Test. In Microbiological Methods. Edited by Collins CH, Lyne PM. London: Butterworth and Co; 1976:235.

27. LeDuy A, Zajic JE: A geometrical approach for differentiation of an experimental function at a point: applied to growth and product formation. Biotechnol Bioeng 1973, 15:805-810

28. Boruwa J, Kalita K, Barua NC, Borah JC, Mazumder S, Thakur D, Gogoi DK, Bora TC: Synthesis, absolute stereochemistry and molecular design of the new antifungal and antibacterial antibiotic produced by Streptomyces sp. 201. Bioorg Med Chem Lett 2004, 14:3571-3574.

29. Eliopoulos GM, Eliopoulos CT: Antibiotic combinations: should they be tested? Clin Microbiol Rev 1988, 1(2):139-156.

30. Eliopoulos GM, Moellering RC: Antimicrobial Combinations. In Antibiotics in Laboratory Medicine. 4th edition. Edited by Lorain V. Baltimore, Md, USA: The Williams and Wilkins company; 1996:330-396.

31. Cruishank R, Duguid JP, Marmion BP, Swain RHA: Medical Microbiology. In The Practice of Medical Microbiology. 12th edition. London, UK: Churchill Livingstone; 1975.

32. Pankuch GA, Jacobs MR, Appelbaum PC: Study of comparative antipneumococcal activities of penicillin G, RP 59500, erythromycin sparfloxacin, ciprofloxacin, and vancomycin by using time-kill methodology. Antimicrob Agents Chemother 1994, 38(9):2065-2072.

33. Baltch AL, Smith RP, Rite WJ, Bopp LH: Comparison of inhibitory and bactericidal activities and postantibiotic effects of LY333328 and ampicillin used singly and in combination against vancomycin-resistant Enterococcus faecium. Antimicrob Agents Chemother 1998 42(10):2564-2568.

34. Gomez KA, Gomez AA: A Statistical Procedure for Agricultural Research. 2nd edition. New York: John Willy and Sons; 1984:188-191.

35. Pridham TG, Hesseltine CW, Benedict RG: A guide for the classification of streptomycetes according to selected groups. Placement of strain in morphological sections. Appl Microbiol 1958, 6:52-79.

36. Pankey GA, Sabath LD: Clinical relevance of bacteriostatic versus bactericidal mechanisms of action in the treatment of gram-positive bacterial infections. Clin Infect Dis 2004, 38:864-870.

37. Fiedler HP, Bruntner C, Bull AT, Ward AC, Goodfellow M, Potterat O, Puder C, Mihm G: Marine actinomycetes as a source of novel secondary metabolites. Ant $v$ Leeuw 2004, 87:37-42.

38. Phoebe CH Jr, Combie J, Albert FG, Van TK, Cabrera J, Correira HJ, Guo Y, Lindermuth J, Rauert N, Galbraith W, Selitrenikoff CP: Extremophilic organisms as an unexplored source of antifungal compounds. J Antibiot 2001, 54:56-65.

39. Glover JB: Applications of Fungal Ecology in the Search of new Bioactive Natural Products. In The Mycota IV: Environmental, Microbial Relationships. Edited by Wicklow DT, Söderström BE. Berlin Heidelberg: Springer-Verlag; 1995:249-268.

40. Thumar JT, Dhulia K, Singh SP: Isolation and partial purification of an antimicrobial agent from halotolerant alkaliphilic Streptomyces aburaviensis strain Kut-8. World J Microbiol Biotechnol 2010, 26:2081-2087.

41. Scherrer R, Gerhardt P: Molecular sieving by the Bacillus megaterium cell wall and protoplast. J Bacteriol 1971, 107:718-735.

42. Cruz R, Arias ME, Soliveri J: Nutritional requirements for the production of pyrazoloisoquinolinone antibiotics by Streptomyces griseocarneus NCIMB 40447. Appl Microbiol Biotechnol 1999, 53:115-119.

43. Calvo AM, Wilson RA, Bok JW, Keller NP: Relationship between secondary metabolism and fungal development. Microbiol Mol Biol Rev 2002 66:447-459.

44. Vilches C, Mendez C, Hardisson C, Salas JA: Biosynthesis of oleandomycin by Streptomyces antibioticus: influence of nutritional conditions and development of resistance. J Gen Microbio/ 1990, 136:1447-1454.
45. Iwai $Y$, Omura S: Cultural conditions for screening of new antibiotics. J Antibiot 1982, 35:123-141.

46. Guimaraes LM, Furlan RL, Garrido LM, Ventura A, Padilla G, Facciotti MC: Effect of $\mathrm{pH}$ on the production of the antitumor antibiotic retamycin by Streptomyces olindensis. Biotechnol Appl Biochem 2004, 40(1):107-111.

47. Griffiths DJ, Saker ML: The Palm island mystery disease 20 years on: a review of research on cyanotoxin cylindrospermopsin. Inc Environ Toxicol 2003, 18:78-93.

48. Egorov NS: Antibiotics a Scientific Approach. Moscow: Mir Publishers; 1985:151.

49. Srinivasan MC, Laxman RS, Deshpande MV: Physiology and nutritional aspects of actinomycetes: an overview. World J Microbiol Biotechnol 1991 7:171-184

50. Gogoi DK, Deka Boruah HP, Saikia R, Bora TC: Optimization of process parameters for improved production of bioactive metabolite by a nove endophytic fungus Fusarium sp. DF2 isolated from Taxus wallichiana of North East India. World J Microbiol Biotechnol 2008, 24:79-87.

51. Tabrizi SG, Hamedi J, Mohammadipanah F: Screening of soil actinomycetes against salmonella server typhi NCTC 5761 and characterization of the prominent active strains. Iran J Microbiol 2013, 5(4):356-365.

52. Remya M, Vijayakumar R: Isolation and characterization of marine antagonistic actinomycetes from west coast of India. Facta Univ Med Biol 2008, 15:13-19.

53. Saha M, Ghosh D Jr, Ghosh D, Garai D, Jaisankar P, Sarkar KK, Dutta PK, Das S, Jha T, Mukherjee J: Studies on the production and purification of an antimicrobial compound and taxonomy of the producer isolated from the marine environment of the Sundarbans. Appl Microbiol Biotechnol 2005, 66:497-505.

54. Taechowisan T, Lu C, Shen Y, Lumyong S: Secondary metabolites from endophytic Streptomyces aureofaciens emuac130 and their antifungal activity. Microbiology 2005, 151:1651-1695.

55. Gold HS, Moellering RC: Antimicrobial-drug resistance. New Eng J Med 1996, 335:1445-1453.

56. Smith TL, Pearson ML, Wilcox KR: Emergence of vancomycin resistance in Staphylococcus aureus. New Eng J Med 1999, 340:493-501.

57. Niederman MS: Is "crop rotation" of antibiotics the solution to a "resistant" problem in the ICU? Am J Resp Crit Care Med 1997, 156:1029-1031.

doi:10.1186/s12866-014-0278-3

Cite this article as: Singh et al:: Production of potent antimicrobial agent by actinomycete, Streptomyces sannanensis strain SU118 isolated from phoomdi in Loktak Lake of Manipur, India. BMC Microbiology 2014 14:278

\section{Submit your next manuscript to BioMed Central and take full advantage of:}

- Convenient online submission

- Thorough peer review

- No space constraints or color figure charges

- Immediate publication on acceptance

- Inclusion in PubMed, CAS, Scopus and Google Scholar

- Research which is freely available for redistribution 